\title{
Genes Up- or Down-regulated by High Calcium Medium in Parathyroid Tissue Explants from Patients with Primary Hyperparathyroidism
}

\author{
KISHIKO NAKAJIMA' ${ }^{1)}$, TOMOKI OKAZAKI'2), TAKAHIRO OKAMOTO ${ }^{3)}$, HIRONARI KIMURA ${ }^{1), 4)}$, \\ KAZUE TAKANO ${ }^{1)}$ AND KANJI SATO ${ }^{1), 4)}$ \\ ${ }^{1)}$ Department of Medicine, Institute of Clinical Endocrinology, Tokyo Women's Medical University, Tokyo 162-8666, Japan \\ ${ }^{2)}$ Department of Biochemistry, Teikyo Medical University, Tokyo 173-8605, Japan \\ ${ }^{3)}$ Department of Surgery, Institute of Clinical Endocrinology, Tokyo Women's Medical University, Tokyo 162-8666, Japan \\ ${ }^{4)}$ Field of Pathophysiology and Treatment for Thyroid and Parathyroid Diseases, Division of Internal Medicine, Graduate School of \\ Medicine, Tokyo Women's Medical University, Tokyo 162-8666, Japan
}

\begin{abstract}
To investigate genes modulated in the parathyroid glands by calcium, expression levels of mRNA for all genes expressed in parathyroid tissue explants (PTEs) obtained from patients with primary hyperparathyroidism ( $\mathrm{I}^{\circ}$-HPT) were analyzed by oligo-DNA microarray. PTEs obtained from 4 patients with $\mathrm{I}^{\circ}$-HPT were precultured in normocalcemic medium $\left(\mathrm{Ca}^{++} 1.0-1.1 \mathrm{mM}\right)$ for 7 days and then cultured in hypocalcemic medium $\left(\mathrm{Ca}^{++} 0.60 \mathrm{mM}\right)$ or hypercalcemic $\left(\mathrm{Ca}^{++}\right.$ $1.60 \mathrm{mM}$ ) medium containing 4mg/dL phosphate for an additional 7 days. As expected, expression levels of mRNA for PTH and chromogranin A were decreased to less than 50\% in the hypercalcemic medium when compared with those in the hypocalcemic medium. Furthermore, oligo-DNA microarray analyses revealed that 7 genes were up-regulated by more than 2-fold and more than 30 genes were down-regulated by more than 1/2 in PTEs. Interestingly, 9 of these genes (upregulated genes: chemokine ligand 8, multiple $\mathrm{C} 2$ domain and transmembrane region protein 1; down-regulated genes: matrix metallopeptidase-9, B-box and SPRY domain-containing protein, nitric oxide synthase 2A, PTH, cartilage acidic protein 1, chromogranin A, and fibrin 1) were involved in calcium metabolism or calcium-signaling pathways in the parathyroid tissue. However, the expression level of mRNA for $\alpha$-klotho was variable, and it was not constantly decreased in hypercalcemic medium under the present experimental conditions. Although it was not possible to use normal parathyroid tissue, this is the first reported study to have investigated the expression levels of mRNA for all genes in human parathyroid adenomas that are modulated by high calcium concentration in organ culture.
\end{abstract}

Key words: Calcium, Parathyroid gland, Primary hyperparathyroidism, Microarray

THE PARATHYROID GLANDS are tiny endocrine glands that play an important role in the regulation of calcium and phosphate concentration. However, the total gene gene expression profile of the parathyroid glands has been scarcely investigated, as they are the smallest of all endocrine organs and usually impossible to obtain as study specimens from normal humans. Although a few studies of calcium-regulating genes

Received Oct. 30, 2009; Accepted Nov. 12, 2009 as K09E-321 Released online in J-STAGE as advance publication Dec. 1, 2009

Correspondence to: Kanji SATO, M.D., Ph.D., Institute of Clinical Endocrinology, Tokyo Women’s Medical University, Kawada-cho 8-1, Shinjuku-ku, Tokyo 162-8666, Japan.

E-mail: satokan@attglobal.net have been done by microarray using frozen parathyroid tissue or parathyroid tissue that has been immediately submerged in an RNAase inhibitor [1-3], there have been no published investigations of all the genes expressed in cultured parathyroid tissue.

Recently, we established an organ culture system for parathyroid tissue explants (PTEs) in which PTH release and the calcium-sensing receptor (CaSR) can be maintained for a prolonged period (up to 4 weeks) [4]. Using this system, we have already found that both the expression level of PTH mRNA and PTH release are significantly increased when PTEs are cultured in high-phosphate medium. In the present study, we cultured PTEs (obtained from patients with prima- 
ry hyperparathyroidism; $\mathrm{I}^{\circ}$-HPT) in hypocalcemic and hypercalcemic medium, and investigated the genes that were up- or down-regulated.

\section{Materials and Methods}

\section{Origin of human parathyroid tissues}

This study was approved by the Ethic Committee of Tokyo Women's Medical University, and informed written consent was obtained from the patients prior to parathyroidectomy [4]. The corrected calcium concentration was $10.7 \pm 0.26 \mathrm{mg} / \mathrm{dL}$ (normal range; 8.5$9.9 \mathrm{mg} / \mathrm{dL}$ ), and the serum level of intact PTH was $187 \pm 62 \mathrm{pg} / \mathrm{mL}$ (normal range; 15-60pg/mL). Usually about $100 \mathrm{mg}$ of parathyroid tissue was obtained from the I'-HPT patients at parathyroidectomy. The parathyroid tissues were dissected into small pieces $(1 \mathrm{x}$ $1 \times 0.5 \mathrm{~mm}$ ), and the explants were placed on a piece of collagen-coated nylon mesh supported by a silicone tube ring so that the mesh was only slightly submerged beneath the surface of the culture medium, in a 6-cm culture dish, as described previously. They were precultured in minimal essential medium (MEM) supplemented with $10 \%$ fetal calf serum (FCS; total calcium concentration 12-14 mg/dL, phosphate concentration 9-11 mg/dL)), $100 \mathrm{U} / \mathrm{mL}$ penicillin and 100 $\mu \mathrm{g} / \mathrm{mL}$ streptomycin (preculture medium) for seven days (total Ca concentration $7.0 \mathrm{mg} / \mathrm{dL}, \mathrm{Ca}^{++}$concentration: $1.0-1.1 \mathrm{mM}$, total phosphate concentration; $4.0 \mathrm{mg} / \mathrm{dL}$ ), and then cultured in MEM containing a low (total Ca $4.0 \mathrm{mg} / \mathrm{dL}$; $\mathrm{Ca}^{++} 0.60 \mathrm{mM}$ ) or high (total Ca $10 \mathrm{mg} / \mathrm{dL}$; $\mathrm{Ca}^{++} 1.60 \mathrm{mM}$ ) calcium concentration. In each experiment, calcium $\left(\mathrm{CaCl}_{2}\right)$ and phosphate $\left(\mathrm{NaH}_{2} \mathrm{PO}_{4}\right.$ and $\left.\mathrm{Na}_{2} \mathrm{HPO}_{4}\right)$ were added to MEM, which had been specially prepared without calcium and phosphate (Invitrogen, Life Science Technologies, Frederick, MD, USA), so that the final total calcium concentration became $4.0 \mathrm{mg} / \mathrm{dL}$ (hypocalcemic medium), $7.0 \mathrm{mg} / \mathrm{dL}$ (normocalcemic medium) or $10 \mathrm{mg} /$ $\mathrm{dL}$ (hypercalcemic medium). The final phosphate concentration was prepared to $1.29 \mathrm{mM}(4.0 \mathrm{mg} / \mathrm{dL})$. $\mathrm{Ca}^{++}$concentration was determined using a ChibaCorning calcium-pH analyzer (Corning, Halstead, Essex, UK). In these hypo- and hypercalcemic media, PTH release from PTEs was significantly increased or decreased, respectively [4], although the set point of PTEs from patients with I ${ }^{\circ}$-HPT was slightly shifted to the right $\left(\mathrm{Ca}^{++}\right.$1.2-1.4 mM) [4] compared with that of normal subjects $\left(\mathrm{Ca}^{++} 1.0-1.2 \mathrm{mM}\right)$.
After an additional 7 days of culture, total RNA was extracted from the parathyroid tissue explants as described previously [4].

\section{Oligo-DNA microarray}

After the RNA had been extracted, oligo-DNA microarray was performed as described previously [4]. In brief, RNA was converted to cDNA using a Human cDNA System I Direct Kit (NEN Life Science Products). cDNA obtained from parathyroid tissues cultured in the control and treated media was labeled with Cy3 (green, low calcium) and Cy5 (red, high calcium), respectively, and the expression levels of 41000 gene spots were analyzed using cDNA microarray (Whole Human Genome Oligo Microarray Kit, Product Number G4112A; Agilent Technologies, Palo Alto, CA). Laser detection of the Cy3 and Cy5 signals on the microarray was performed with a non-confocal laser reader, Gene PX 4000A (Axon Instruments, Union, CA). Fluorescence signal intensities and the Cy5/Cy3 ratios for each of the 41000 oligo-DNAs were analyzed using the Gene PixPro 30 software package (Axon Instruments).

\section{Data analysis}

The data from all arrays were analyzed using GeneSpring GX software (Agilent Technologies UK Limited, South Queensferry, UK) [6]. Array normalization was done using the intensity-dependent Lowess normalization method. Analysis was performed on the log expression ratios that were produced in the normalization step. Biological replicates were treated as duplicate measurements, and their averages were calculated. Features that were flagged absent in all the arrays and non-reliable features with a very low signal were removed prior to further analysis. The normalized data were analyzed to identify genes whose expression appeared to be up- or downregulated by an arbitrary cut-off of at least 2-fold.

The microarray data discussed in this publication have been deposited in the Gene Expression Omnibus (GEO; www.ncbi.nlm.nih.gov/geo/info/linking.html) of the National Cancer for Biotechnology Information, and are accessible through GEO series accession number GSE 18689).

\section{Real-time RT-PCR}

Total RNA (250 ng) was reverse-transcribed in a total reaction volume of $100 \mathrm{~mL}$ using a high-capacity 


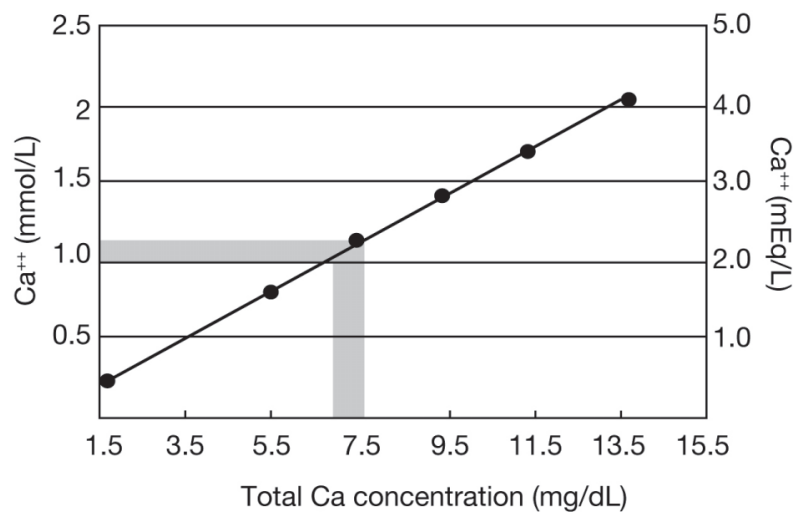

Fig. 1. Total and ionized calcium concentration in the culture medium

PTEs were cultured in minimal essential medium (MEM; Ca $7.0 \mathrm{mg} / \mathrm{dL}$ ) supplemented with $10 \%$ fetal calf serum (FCS) for seven days $\left(\mathrm{Ca}^{++}\right.$concentration $\left.1.0 \mathrm{mM}\right)$, and then cultured with low $\left(4.0 \mathrm{mg} / \mathrm{dL}, \mathrm{Ca}^{++} 0.60 \mathrm{mM}\right)$ or high (total Ca $10 \mathrm{mg} / \mathrm{dl}, \mathrm{Ca}^{++} 1.60 \mathrm{mM}$ ) calcium concentration for an additional 7 days. Normal $\mathrm{Ca}^{++}$ concentration is $1.0-1.2 \mathrm{mM}$.

cDNA archive kit (Applied Biosystems, Foster City, CA) in accordance with the manufacturer's instructions, and real-time PCR was performed as described previously [5]. Five assays were performed: PTH (Hs00174888_m1), chromogranin A (Hs00154441_ m1), CaSR (Hs01047793_m1) VDR (Hs01045845_ g1) and $\alpha$-klotho (Hs00183100_m1), using 18S rRNA (Hs99999901_s1) as a control.

In each case, triplicate threshold cycle (Ct) values were obtained and averaged, and the expression levels were then evaluated using a relative quantification method. The fold change in target genes was normalized to the 18S rRNA (reference gene) and compared with the control (calibrator) sample, using the formula: Fold change $=2^{-\Delta \Delta \mathrm{Ct}}$, where $\Delta \Delta \mathrm{Ct}=(\mathrm{Ct}$-target-Ctreference) sample-n - (Ct-target - Ct-reference) calibrator-sample. Sample-n corresponds to any sample for the target gene normalized to the reference gene, and calibrator-sample represents the expression level (1x) of the target gene normalized to the reference gene.

\section{Statistical analysis}

All data are expressed as mean $\pm \mathrm{SE}$. Correlations between the levels of expression of mRNA for PTH, CaSR and klotho were analyzed using Pearson's correlation coefficient test. Statistical significance was set at $P<0.05$.

\section{Results}

\section{Relationship between total and ionized calcium con- centrations}

As shown in Fig.1, there was a good correlation between the total and ionized calcium $\left(\mathrm{Ca}^{++}\right)$concentrations. A normal ionized calcium concentration (1.0-1.2 $\mathrm{mM}$ ) was obtained at a total calcium concentration of 6.8-7.5 mg/dL in culture medium containing 10\% FCS.

\section{Genes up- and down-regulated by calcium in PTEs from patients with $I^{\circ}$-HPT}

Preliminary experiments revealed that without preculture in normocalcaemic medium for 7 days, mRNA expression levels of PTH and chromogranin A were not constantly decreased in the hypercalcemic medium. Therefore, all experiments were preformed after 7 days of preculture in the normocalcaemic medium. After 24h culture in the hypercalcemic medium, mRNA expression levels of PTH and chromogranin A were suppressed and both mRNA expression levels were suppressed to less than $1 / 2$ in hypercalcemic medium (when compared with those cultured in the hypocalcemic medium) for more than 14days (data not shown).

When PTEs were cultured in high $\mathrm{Ca}^{++}$medium for 7 days (Tables 1, 2 \& Fig.2) [7, 8], levels of expression of mRNA for PTH and chromogranin A were decreased to less than 50\%. Analyses by GeneSpringGX revealed that 7 genes were up-regulated more than 2-fold, and that more than 30 genes were down-regulated to less than 1/2 in PTEs obtained from 4 patients with I'-HPT (Table 1). Unsurprisingly, 9 of these genes (up-regulated genes: chemokine ligand 8 [CCL8], multiple C2 domain and transmembrane region protein 1 [MCTP1]; down-regulated genes: matrix metallopeptidase-9 [MMP9], B-box and SPRY domain-containing protein [BSPRY], nitric oxide synthase 2A [NOS2A], parathyroid hormone [PTH], cartilage acidic protein 1 [CRTAC1], chromogranin A [CHGA], and fibrin 1 [FBLN1]) were related to PTH secretion or calcium-signaling pathways.

To confirm the microarray data, we investigated mRNA expression levels by real-time PCR. However, we were able to perform only one experiment, since the amount of total RNA was very low, and could be used only for microarray analyses. Real time PCR in experiment 4 (Table 2) demonstrated that levels of expression of mRNA for PTH, chromogranin A, CaSR 
Table 1. Genes up- and down-regulated genes by calcium in PTE obtained from patients with I-HPT

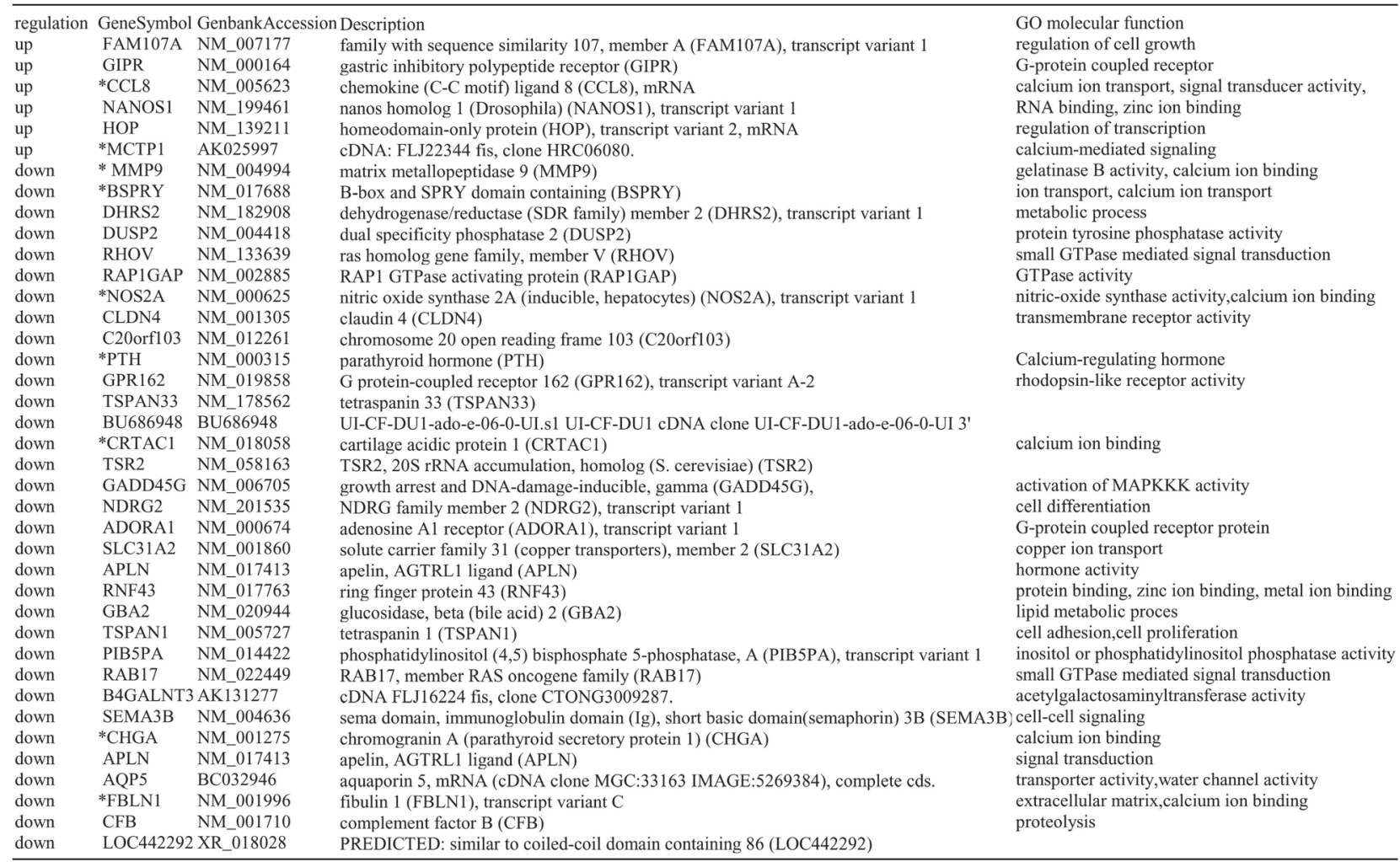

* indicates genes involved calcium metabolism or calcium-mediated process.
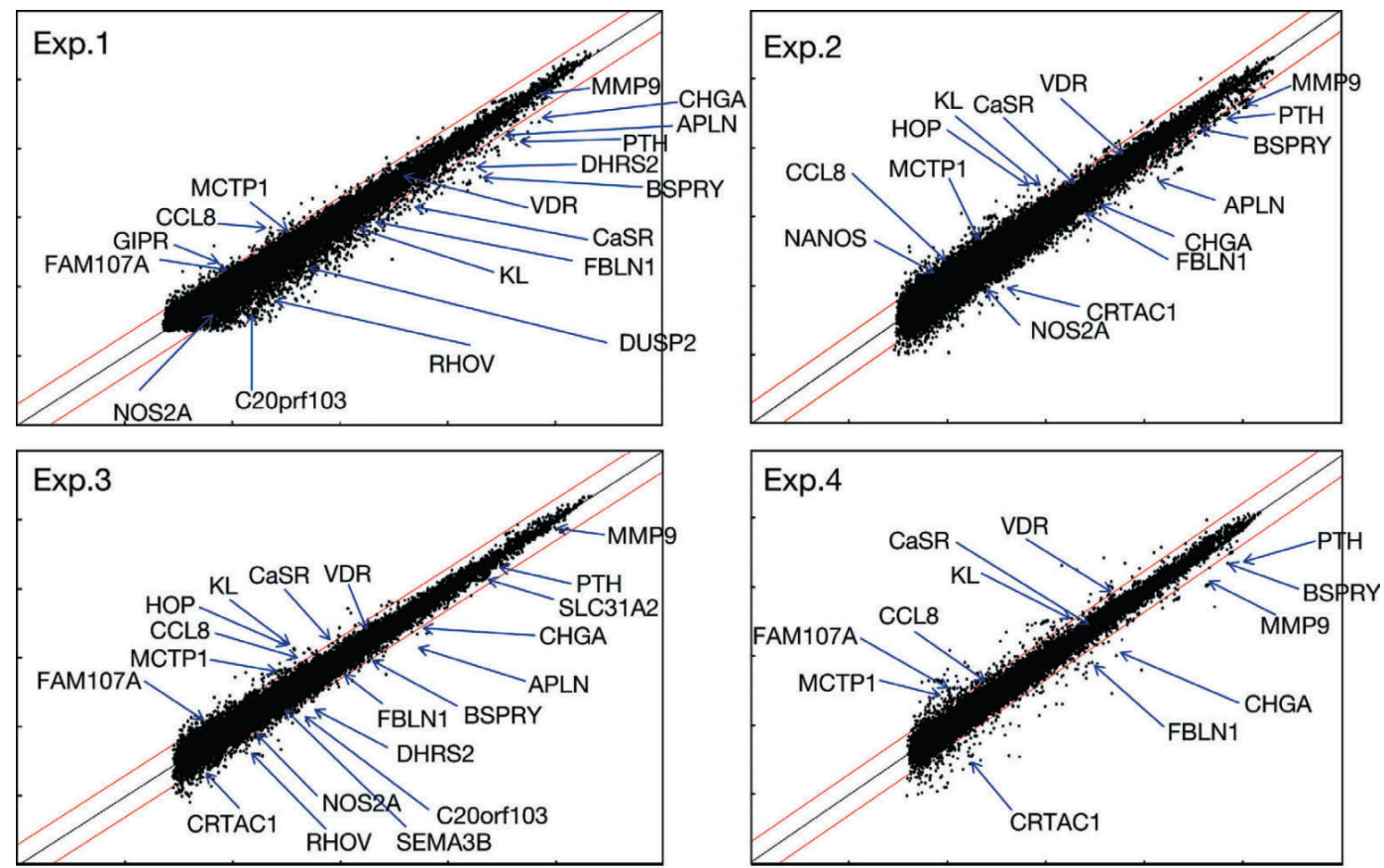

Fig. 2. Scatter plot of genes expressed in PTEs cultured in low $\left(\mathrm{Ca}^{++} 0.60 \mathrm{mM}\right)$ or high $\left(\mathrm{Ca}^{++} 1.60 \mathrm{mM}\right)$ calcium medium for 7 days PTEs were precultured for 7 days in normocalcaemic medium and then cultured in either hypocalcemic $\left(\mathrm{Ca}^{++} ; 0.6 \mathrm{mM}\right)$ or hypercalcemic $\left(\mathrm{Ca}^{++} ; 1.60 \mathrm{mM}\right)$ medium containing $1.29 \mathrm{mM}(4.0 \mathrm{mg} / \mathrm{dL})$ phosphate. After an additional 7 days of culture, total RNA was extracted and whole human genes were analyzed by oligo-DNA microarray as described in Materials and Methods. 
Table 2. mRNA expression levels of PTH, chromogranin-A, CaSR, VDR, and $\alpha$-klotho Cy5/cy3 ratio of genes involved in calcium metabolism

\begin{tabular}{lccccc} 
& PTH & CHGA & CaSR & VDR & $\alpha$-klotho \\
\hline Exp.1 & 0.26 & 0.34 & 0.38 & 0.95 & 0.46 \\
Exp.2 & 0.47 & 0.42 & 1.57 & 1.36 & 3.84 \\
Exp.3 & 0.63 & 0.35 & 1.53 & 1.10 & 3.75 \\
Exp.4 & 0.27 & 0.23 & 1.32 & 1.84 & 2.19 \\
\hline
\end{tabular}

$\begin{array}{llllll}\text { Mean } \pm \text { SEM } & 0.41 \pm 0.09 & 0.34 \pm 0.04 & 1.20 \pm 0.28 & 1.31 \pm 0.2 & 2.56 \pm 0.8\end{array}$

and $\alpha$-klotho were $0.18,0.61,1.17$ and 3.08, respectively, thus confirming the microarray data.

\section{Level of expression of $\alpha$-klotho mRNA and its rela- tionship with calcium-regulating genes}

Although levels of expression of $\alpha$-klotho mRNA and protein are decreased in patients with $\mathrm{I}^{\circ}$-HPT [9], they were very variable under the present experimental conditions. In one experiment, they were suppressed accompanied by suppressed expression of CaSR and $\mathrm{PTH}$, but increased in the other three experiments accompanied by non-suppressed expression of CaSR (Table 2). Statistical analyses revealed that although there was a marginal correlation between CaSR and $\alpha$-klotho ( $P=0.055$ ), it was not statistically significant, probably due to the low number of experiments.

\section{Discussion}

Using PTEs obtained from patients with $\mathrm{I}^{\circ}$-HPT, we have for the first time demonstrated the expression levels of all genes modulated by calcium concentration using long-term culture in the presence of low and high calcium. As expected, we demonstrated that the expression levels of mRNA for PTH and chromogranin A were decreased to less than $50 \%$ when PTEs were cultured in hypercalcemic medium $[7,8]$.

As is well known, expression levels of mRNA for CaSR and VDR are decreased in the parathyroid gland in patients with $\mathrm{I}^{\circ}$-HPT [10]. Although we could not compare the mRNA expression levels of these genes with those of normal parathyroid tissue, CaSR and VDR were moderately expressed in PTEs obtained from patients with I०-HPT (Fig. 2).

It should be pointed out that 9 of 39 genes were involved in PTH release or calcium-signaling pathways. MCTP1, one of several $\mathrm{C}_{2}$ domain proteins with unusual $\mathrm{Ca}^{++}$binding properties [11], showed increased expression when cultured in high calcium medium.
Since most $C_{2}$ domain proteins are either signal transduction enzymes, such as protein kinase $\mathrm{C}$, or membrane trafficking proteins, such as synaptotagmin 1 [11], it would be involved in $\mathrm{Ca}^{++}$signal transduction in the parathyroid gland. Furthermore, CCL8, a chemokine previously known as monocyte chemoattractant protein 2 (MCP-2), was increased in high $\mathrm{Ca}^{++}$ medium. When MCP-1 and MCP-3, but not MCP-2, bind to their chemokine receptor in monocytes, the intracellular $\mathrm{Ca}^{++}$concentration increases [12]. However, CCL8 can induce $\mathrm{Ca}^{++}$influx as potently as MCP-1 in human embryonic kidney 293-EBNA cells transfected with the MCP-1 receptor [13], and also induces a robust, pertussis toxin-sensitive calcium flux in primary lymphocytes [14]. The pathophysiological significance of these in vitro findings also remains to be elucidated.

PTH is known to stimulate endothelial nitric oxide synthase through the protein kinase A and C pathways [15]. Consistent with these in vitro findings, the expression of NOS2A, probably in endothelial cells or parathyroid cells in the PTEs, was decreased to less than $1 / 2$. BSPRY, which is involved in the regulation of epithelial $\mathrm{Ca}^{++}$transport by direct association with transport receptor potential vallinoid (TRPV5) in the kidney [16], was also decreased to less than $1 / 2$, and its role in parathyroid tissue remains to be elucidated. Furthermore, MMP9 expression is known to be stimulated by PTH in bone cells [17] and its expression was confirmed in parathyroid tissues [18]. Then, our finding that high calcium concentration inhibited MMP9 expression in the parathyroid adenoma might be secondary consequence of suppression of PTH expression rather than a change in calcium level by itself. Similarly, while CRTAC1 is reported to function as a calcium-binding protein in synovium [19], an alteration of PTH expression by a shift of calcium concentrations in our experiments might well affect its expression in the parathyroid gland.

$\alpha$-klotho was originally characterized as an agingrelated gene [20], and its mRNA expression is confined to renal tubules, the choroid plexus and parathyroid glands [21]. Recently, Imura et al. reported that, when parathyroid glands are cultured in low Ca medium, $\mathrm{Na}^{+} \mathrm{K}^{+}$-ATP and $\alpha$-klotho are acutely activated and transported to the plasma membrane and PTH is immediately secreted [22, 23]. CaSR seems not to be involved in this acute hypocalcemia control system [24]. Furthermore, Björklund et al. [9] reported that 
$\alpha$-klotho mRNA expression was decreased in parathyroid tissue in patients with $\mathrm{I}^{\circ}$-HPT, and that its expression level was suppressed at supraphysiological $\mathrm{Ca}^{++}$concentrations (3-4 mM) in vitro [9]. Although the expression level of mRNA for $\alpha$-klotho was suppressed in 1 of 4 experiments, it was not suppressed in the other three under the present experimental conditions. We did not culture PTEs in medium containing 3-4 $\mathrm{mM} \mathrm{Ca}^{++}$, since dystrophic or metastatic calcification occurs in such supraphysiologically hypercalcemic medium during prolonged culture (our unpublished observation). The role of $\alpha$-klotho in patients with $\mathrm{I}^{\circ}$-HPT remains to be elucidated in future studies.

In summary, by culturing PTEs obtained from patients with $\mathrm{I}^{\circ}$-HPT in medium containing a low or high calcium concentration, we have demonstrated for the first time that 9 genes are constantly up-regulated and that more than 30 genes are down-regulated to less than $1 / 2$ by calcium. A number of these genes are involved in PTH release or calcium-signaling pathways.

\section{Acknowledgements}

This work was partly supported by Grants-in-Aid for Scientific Research from the Ministry of Education, Science and Culture of Japan (no. 20591102). We thank Dr. Azuma (Teijin Pharma, Tokyo) for measuring $\mathrm{Ca}^{++}$ concentrations in culture medium, and Mr. Kazufumi Watanabe (Hokkaido System Sciences, Hokkaido) for performing analysis using GeneSpring GX.

\section{References}

1. Santamaría I, Alvarez-Hernández D, Jofré R, Polo JR, Menárguez J, Cannata-Andía JB (2005) Progression of secondary hyperparathyroidism involves deregulation of genes related to DNA and RNA stability. Kidney Int 67: 2267-2279.

2. Rosen JE, Costouros NG, Lorang D, Byrbs AL, Alexander HR, Skarulis MC, Cochran C, Pingpank JF, Marx SJ, Spiegel AM, Libutti SK (2005) Gland size is associated with changes in gene expression profiles in sporadic parathyroid adenoma. Ann Surg Oncol 12: 1-5.

3. Velázquez-Fernández D, Laurell C, Saqui-Salces M, Pantoja JP, Candanedo-Gonzalez F, Reza-Albarrán A, Gamboa-Dominguez A, Herrera MF (2006) Differential RNA expression profile by cDNA microarray in sporadic primary hyperparathyroidism (pHPT): primary parathyroid hyperplasia versus adenoma. World J Surg 30: 705-713.

4. Nakajima N, Umino K, Azuma Y, Kosaka K, Takano T, Obara T, Sato K. (2009) Stimulating parathyroid cell proliferation and PTH release with phosphate in organ cultures obtained from patients with primary and secondary hyperparathyroidism for a prolonged period. $J$ Bone Miner Metab 27: 224-233.

5. Yamazaki K, Suzuki K, Emiko Yamada E, Yamada T, Takeshita F, Matsumoto M, Mitsuhashi T, Obara T, Takano K, Sato K (2007) Suppression of iodide uptake and thyroid hormone synthesis with stimulation of type I interferon system by double-stranded RNA (dsRNA) in cultured human thyroid follicles. Endocrinology 48: 3226-3235.

6. Weidenfeld-Baranboim K, Hasin T, Darlyuk I, Heinrich1 R, Elhanani O, Pan J, Yokoyama K,
Aronheim1 A. (2009) The ubiquitously expressed bZIP inhibitor, JDP2, suppresses the transcription of its homologue immediate early gene counterpart, ATF3. Nucleic Acids Research 37: 2194-2203.

7. Cohn DV, Fasciotto BH, Reese BK, Zhang JX (1995) Chromogranin A: a novel regulator of parathyroid gland secretion. J Nutr 125(7 Suppl): 2015S-2019S.

8 Angeletti RH, D’Amico T, Russell J (2000) Regulation of parathyroid secretion. Chromogranins, chemokines, and calcium. Adv Exp Med Biol 482: 217-223.

9. Björklund P, Krajisnik T, Akerström G, Westin G, Larsson TE (2008) Type I membrane klotho expression is decreased and inversely correlated to serum calcium in primary hyperparathyroidism. J Clin Endocrinol Metab 93: 4152-4157.

10. Chen RA, Goodman WG (2004) Role of the calciumsensing receptor in parathyroid gland physiology. Am J Physiol Renal Physiol 286: F1005-1011.

11. Shin OH, Han W, Wang Y, Südhof TC (2005) Evolutionarily conserved multiple $\mathrm{C}_{2}$ domain proteins with two transmembrane regions (MCTPs) and unusual $\mathrm{Ca}^{++}$binding properties. J Biol Chem 280: 1641-1651.

12. Proost P, Wuyts A, Van Damme J (1996) Human monocyte chemotactic proteins-2 and -3: structural and functional comparison with MCP-1. J Leukoc Biol 59: 6774.

13. Yamagami S, Tanaka H, Endo N (1997) Monocyte chemoattractant protein-2 can exert its effects through the MCP-1 receptor (CC CKR2B). FEBS Lett 400: 329-332.

14. Yang OO, Garcia-Zepeda EA, Walker BD, Luster AD (2002) Monocyte chemoattractant protein-2 (CC chemokine ligand 8) inhibits replication of human im- 
munodeficiency virus type 1 via CC chemokine receptor 5. Infect Dis 185: 1174-1178.

15. Rashid G, Bernheim J, Green J, Bencheritt S (2007) Parathyroid hormone stimulates the endothelial nitric oxide synthase through protein kinase A and C pathways. Nephrol Dial Transplant 22: 2831-2837.

16. Van de Graaaf SFJ, van der Kemp AWCM, van der Berg D, van Oorschot M, Hoenderop JGJ, Nindels RJM (2006) Identification of BSPRY as a novel Auxiliary protein inhibiting TRPV5 activity. J Am Soc Nephrol 17: 26-30.

17. McClelland P, Onyia JE, Miles RR, Tu Y, Liang J, Harvey AK, Chandrasekhar S, Hock JM, Bidwell JP (1998) Intermittent administration of parathyroid hormone (1-34) stimulates matrix metalloproteinase-9 (MMP-9) expression in rat long bone. J Cell Biochem 70: 391-401.

18. Tomita T, Iwata K (1999) Matrix metalloproteinases and tissue inhibitors of metalloproteinases in some endocrine organs and their tumors. Endocr Pathol 10: 1526.

19. Desai J, Shannon ME, Johnson MD, Ruff DW, Hughes LA, Kerley MK, Carpenter DA, Johnson DK, Rinchik EM, Culiat CT (2006) Nell1-deficient mice have reduced expression of extracellular matrix proteins causing cranial and vertebral defects. Hum Mol Genet 15:
1329-1341.

20. Kuro-o M, Matsumura Y, Aizawa H, Kawaguchi H, Suga T, Utsugi T, Ohyama Y, Kurabayashi M, Kaname T, Kume E, Iwasaki H, Iida A, Shiraki-Iida T, Nishikawa S, Nagai R, Nabeshima YI (1997) Mutation of the mouse klotho gene leads to a syndrome resembling ageing. Nature 390: 45-51.

21. Imura A, Tsuji Y, Murata M, Maeda R, Kubota K, Iwano A, Obuse C, Togashi K, Tominaga M, Kita N, Tomiyama K, Iijima J, Nabeshima Y, Fujioka M, Asato R, Tanaka S, Kojima K, Ito J, Nozaki K, Hashimoto N, Ito T, Nishio T, Uchiyama T, Fujimori T, Nabeshima Y (2007) alpha-Klotho as a regulator of calcium homeostasis. Science 316: 1615-1618.

22. Nabeshima Y (2009) Discovery of alpha-Klotho unveiled new insights into calcium and phosphate homeostasis. Proc Jpn Acad Ser B Phys Biol Sci 85: 125-141.

23. Nabeshima Y, Imura H. (2008) alpha-klotho: a regulator that integrates calcium homeostasis. Am J Nephrol 28: 455-464.

24. Brown EM, Watson EJ, Thatcher JG, Koletsky R, Dawson-Hughes BF, Posillico JT, Shoback DM (1987) Ouabain and low extracellular Potassium inhibit PTH secretion from bovine parathyroid cells by a Mechanism that does not involve increases in the cytosolic calcium concentration. Metabolism 36: 36-42. 